\title{
Evaluation of cauliflower genotypes by different growing method
}

\author{
Gulyás, G., Tóth, A. R. \& Takácsné Hájos M. \\ University of Debrecen, Faculty of Agricultural and Food Sciences and Environmental Management, \\ Institute of Horticultural Science, H-4032 Debrecen, Böszörményi Street 138. \\ Author for correspondence: hajos@agr.unideb.hu
}

\begin{abstract}
Summary: Cauliflower is currently cultivated on 350-400 thousand hectares in the world and around 1500 ha in Hungary. Its cultivation requires considerable expertise as it is sensitive to environmental factors and adequate nutrient supply. The aim of our experiment was to compare three genotypes (Abeni, SV5777 AC and Telergy $F_{1}$ ) by different growing method - under plastic tunnel and on open field. On open field the planting was on $19^{\text {th }}$ of March, 2018, the row and plant distances were 45 and $35 \mathrm{~cm}$. Under plastic tunnel the transplants were set out on the same day with the same genotypes as on open field, with $55 \times 45 \mathrm{~cm}$ arrangement. The results have proved that cauliflower curds from plastic tunnel was two times bigger than on open field. The more protected environment had a positive effect not only on the mass of the curd, but also on the biomass production. Among the examined genotypes Abeni showed the highest yield (about $1 \mathrm{~kg} / \mathrm{plant}$ ) under plastic tunnel. The shape of the head is important for the market. According to our data, we measured the width and height of the curd. Open field conditions induced wider curd with longer stem and caused lower product quality and weaker correlation between the parameters than plastic tunnel.
\end{abstract}

Gulyás, G., Tóth, A. R., Takácsné Hájos, M. (2019): Evaluation of cauliflower genotypes by different growing method. International Journal of Horticultural Science 25(1-2): 11-14. https://doi.org/10.31421/IJHS/25/1-2./2356

Key words: cauliflower, growing method, under plastic, open field

\section{Introduction}

Cauliflower is an important vegetable crop of the Brassicaceae family and is grown worldwide. It has been correctly described as "Aristocrat of cole crops" and is grown for its tender white curds (Nimkar \& Korla, 2014).

Cauliflower is native to ancient Asia Minor. In the Mediterranean region, precisely in Turkey and Italy it is one of the most important vegetables since the $6^{\text {th }}$ century, BC. To the middle of the $16^{\text {th }}$ century it was spread across Europe, there are written records from France, from Northern Europe and even from the British Isles about the cultivation. Nowadays the United States, France, Italy, India and China are the biggest producers of cauliflower (Gregory, 2015).

Cauliflower is harvested in 1.4 million ha worldwide (FAO, 2015). China is the leading producer of cauliflower in the world and contributing 34 percent in area (478.3 thousand ha) and 42.9 percent in production. India is the second major cauliflower producing country after China and contributes 32 percent in area and 36 percent in the world production share (FAO, 2015). Apart from India and China, the other major producers of cauliflower are France, Italy, and the United Kingdom (Sharma et al., 2005).

The brassica family is cold resistant. For the most cole crops a cold period is necessary for flowering. The minimum and maximum growing temperatures for cauliflower are 0 and $30{ }^{\circ} \mathrm{C}$. The optimal growing temperature for this crop is between 15 and $22{ }^{\circ} \mathrm{C}$. High temperatures during cauliflower production delay maturity and increase vegetal growth meanwhile cool temperatures hasten the maturity. Excessive use of fertilizer may contribute to tip burn, hollow stem, internal browning, head rot and other problems (Kerns et al., 1995).

Cauliflower is grown on many different types of soil, but the best is on rich, well-drained soil with a high moistureholding capacity (Helyes et al., 2000).

High humus content in the soil will provide better aeration and water penetration. Well-drained, sandy loam soils are suited to early varieties, whereas loamy and clay loam soils are suited to late ones because they are a little bit tolerant to poor drainage (Stirling \& Lancaster, 2005). Successful cauliflower production requires $130-170 \mathrm{~kg}$ pro hectare nitrogen active agent to improve dark green coloured leaves. The lack of nitrogen can cause light green leaves, eventually turning yellow and may be shed (Astarini et al., 2006).

Phosphorus is important for root development. Cool and wet soil conditions hamper its uptake. Deficiency symptoms include slow growth and delayed maturity. However the excessive potassium may lead to increased tip burn. Cauliflower crops have a high need for sulphur mainly on sandy soils with low organic matter (Delahaut \& Newenhouse, 1997).

The forcing of cauliflower is not typical in autumn or winter time. For early production the unheated plastic tunnel is the most common. The forcing of this species is mainly in early spring time. The planting time is in the end of February or start of March. For early production the tunnel have to be covered with double layered plastic and short season varieties must be used. The heat demand of cauliflower is about $16-20{ }^{\circ} \mathrm{C}$ in the 12-16 leaves stage. The harvest will be expected on the $10-14^{\text {th }}$ week, which can be elongated about 2 weeks. The plants are 
ready to harvest when the wideness of curd is a minimum of 10 $\mathrm{cm}$. Smaller size is not marketable only as second class product.

For the preparation of ready product is necessary to cut the leaves $1 \mathrm{~cm}$ longer than the curds. The expected yield is about $1.5-3.5 \mathrm{~kg} / \mathrm{m}^{2}$ (Hodossi et al., 2004).

\section{Materials and methods}

The experiment was carried out in Nagykereki. The plants were set out on open field and under plastic sheet at the $19^{\text {th }}$ of March, 2018. The aim was the comparison of three cauliflower varieties (Abeni, SV5777 AC, Telergy $F_{l}$ ) by different growing methods. For preparing the growing area on open field there was deep ploughing and giving out of complex fertiliser - Yara Milla Cropcare (11-11-21) $400 \mathrm{~kg}$ per hectare. The arrangement on open field was $45 \times 35 \mathrm{~cm}$ row and plant distance. The growing area was covered with plastic vlies.

Under plastic tunnel the transplants were set out on the same day with the same genotypes as on open field. The growing area was prepared with Bactofil B $10\left(1,51 \mathrm{ha}^{-1}\right)$ which was mixed in the soil $2 \mathrm{~cm}$ deep. The row and plant distances were 55 and $45 \mathrm{~cm}$. After transplanting complex fertiliser (NPK-15-30-10) were got out (4 kg per hectare) with watering. The harvest was one threaded by hand.

The measurements were carried out on the characteristics of plants in plots (10 individuals):

- weight of leaves $(\mathrm{kg})$,

- weight of curd ( $\mathrm{kg})$,

- width of curd $(\mathrm{cm})$,

- height of curd $(\mathrm{cm})$,

- length of stem $(\mathrm{cm})$,

- number of branches,

- weight of stem $(\mathrm{kg})$.

For the statistical analysis we used standard deviation and calculation of correlation coefficient with the excel program.

\section{Results and discussion}

Evaluating different varieties we have stated that the biomass production under plastic tunnel is higher than on open field (Figure 1).

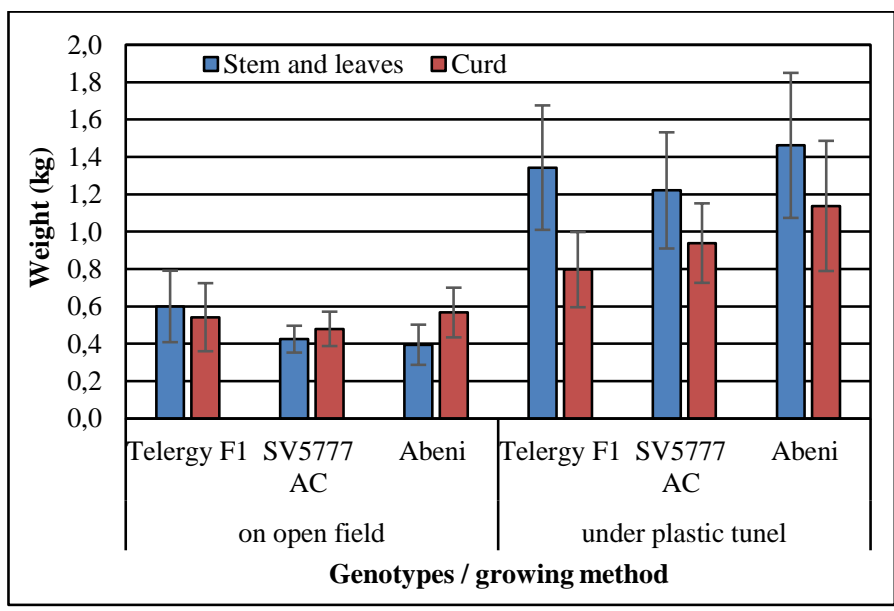

Figure 1. Results of stem, leaves and weight of curd by different cauliflower genotypes and growing method $(n=10$; Nagykereki, 2018)
With more leaves we detected improved curds under plastic tunnel. On open field there was less difference in weight of biomass and curds then under plastic tunnel. It means that the protected environment were favourable on the biomass and curd production. Statistically proved difference were not detected between the genotypes, weight of curds was about 0.5 $\mathrm{kg}$ while under plastic tunnel it was about $1.0 \mathrm{~kg}$. Among the varieties Abeni has showed the highest curd weight in both technologies.

The weight of curd is the most important parameter because it can determine the yield. Varieties with smaller curds are suitable for fresh production while for processing larger curds are preferable.

The width and height of curd is connected to usability of raw material. The wider and smaller curds have shorter stems which are more favourable for the processing. For freezing the curds must be cut into florets, so the stem is only side product. All varieties developed wider curds under plastic tunnel than on open field (Figure 2). At the same time the height of curds was smaller by the protected technology (plastic tunnel). We have proved that the cauliflower produced under plastic tunnel was more favourable for frozen product (florets). Shorter stem length was detected by the varieties under plastic tunnel (Figure 3). The Telergy $F_{1}$ was the most favourable (shortest stem) for this parameter.

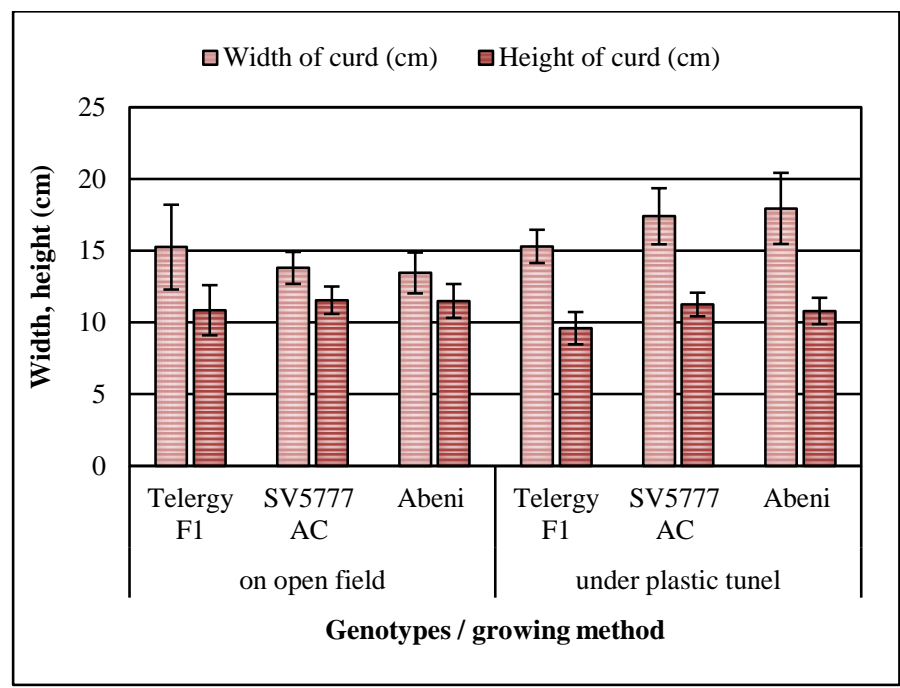

Figure 2. The effect of different growing method on width and height of curds $(\mathrm{n}=10 ;$ Nagykereki, 2018)

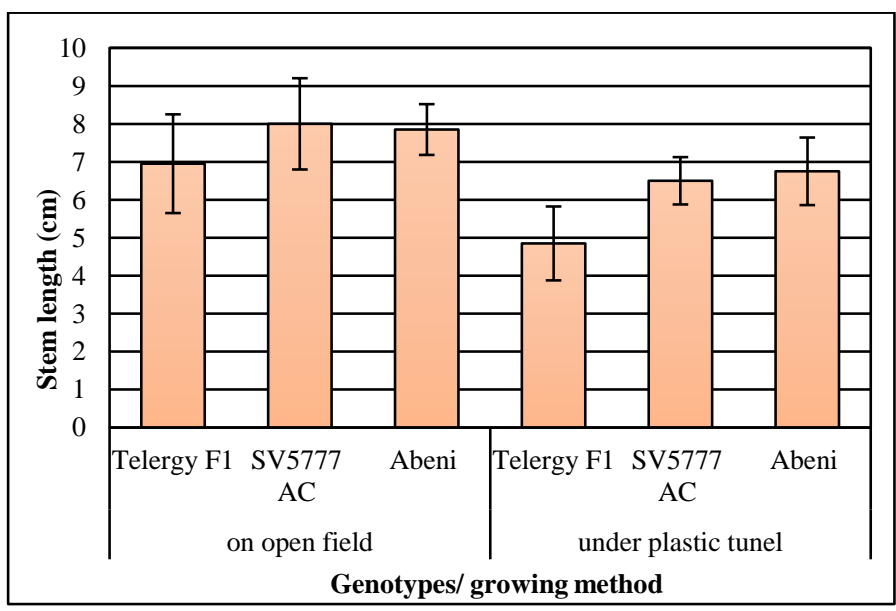

Figure 3. The length of stem in the curd by different genotypes and growing method $(n=10$; Nagykereki, 2018) 
The raw material to freezing is the florets. For this market the florets yield is important. The results of this evaluation are shown on the Figure 1. Higher florets yield was detected under plastic tunnel compared to open field technology. The results were statistically proved.

The number of branching influence of weight of florets. According to the results we have not find difference for this parameter by the different growing methods (Figure 4). It seems that this parameter is genetically coded. On open field the number of branches was the highest (more than 15) by the Telergy $F_{l}$ while under plastic tunnel the Abeni has produced the highest value (about 17).

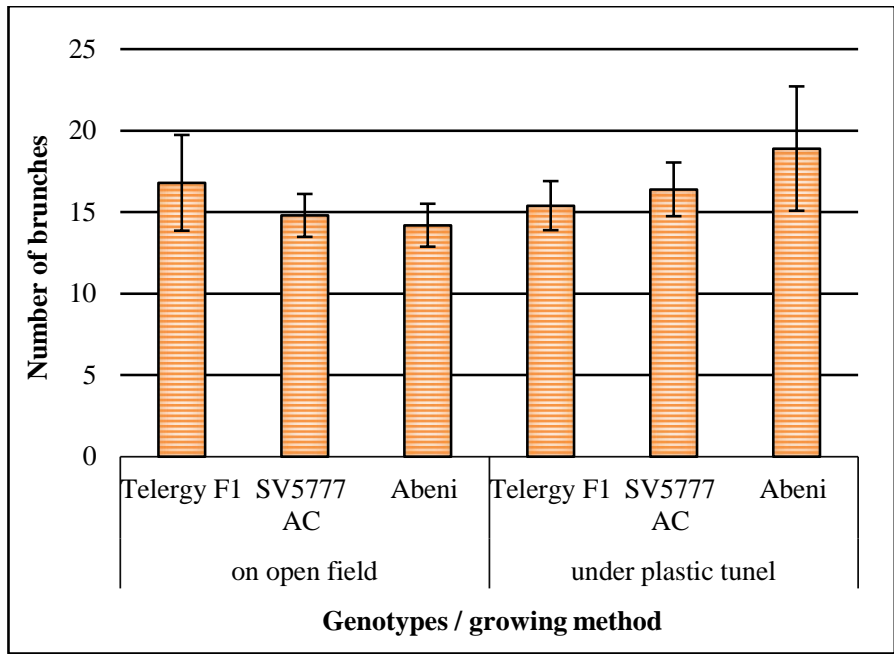

Figure 4. Number of bunches by different genotypes and growing methods

The cauliflower needs balanced water and nutrient supply, so the proper technology is important during the vegetation period. This is the main reason that the cauliflower is the most sensitive between the cole crops during the production. The higher yield and better quality has proved that the production under plastic tunnel was more favourable than on open field. For the evaluation of connection between different morphological parameters under plastic tunnel was used correlation analysis (Table 1).
The correlation between the weight and width of curd (Table 2) was only $\mathrm{r}=0.627$ compared to the same connection under plastic tunnel $(r=0.848)$. Similar tendency was detected between the weight of curd and the number of branches. Tight correlation was detected between the height of curd and the length of stem $(r=0.737)$.

Finally, we can state that different quality parameter was detected on open field in the mean of varieties than under plastic tunnel. The protected surroundings produced more improved curds with higher quality.

\section{Conclusions}

To satisfy the needs of markets it is not necessary to apply modern technology, but it is important to choose the proper genotype and growing method. The results have proved that cauliflower production was higher under plastic tunnel than on open field. It's known that larger curd is connected with higher biomass production, which can be accomplished with higher nutrition supply. On open field the weight of curd was about half of the ones grown under plastic tunnel. The Telergy $F_{1}$ produced the highest weight $(0.5 \mathrm{~kg})$ compared to other varieties on open field, but it was only half of the weight of Abeni $(1.1 \mathrm{~kg}$ ) which developed under plastic tunnel. The proper choice of varieties is very important for the growing method to realise the genetic potential of genotypes. The shape of curd is important not only appearance but for opening of curds (preparing florets), too, which determine the florets' yield. Under plastic tunnel the curds were wider and higher (15 $\mathrm{cm}$ and $10 \mathrm{~cm})$. On open field the varieties produced longer stems $(12-13 \mathrm{~cm})$. The Telergy $F_{1}$ is the only hybrid which improved similar curd (width and height) in both growing methods. According to the results we can state that under plastic cover the florets yield is higher than on open field. The Abeni produced the highest weight of curd (on open field 0.45 $\mathrm{kg}$, under plastic tunnel $1 \mathrm{~kg}$ ). The number of branches is important for the opening of the curds. The florets production is determined by this parameter which is important for frozen product and fresh market, too.

Table 1. Correlation matrix for different quality parameters in the mean of varieties

\begin{tabular}{|c|c|c|c|c|c|c|c|c|c|}
\hline $\begin{array}{c}\text { UNDER PLASTIC } \\
\text { TUNNEL }\end{array}$ & $\begin{array}{l}\text { Weight of } \\
\text { stem leaves } \\
\text { and stem }\end{array}$ & $\begin{array}{l}\text { Weight of } \\
\text { curd }\end{array}$ & $\begin{array}{l}\text { Width of } \\
\text { curd }\end{array}$ & $\begin{array}{l}\text { Height of } \\
\text { curd }\end{array}$ & $\begin{array}{l}\text { Length of } \\
\text { stem }\end{array}$ & $\begin{array}{l}\text { Number of } \\
\text { brunches }\end{array}$ & $\begin{array}{l}\text { Weight of } \\
\text { stem }\end{array}$ & $\begin{array}{l}\text { Weight of } \\
\text { florets }\end{array}$ & $\begin{array}{l}\text { Weight of } \\
\text { compact } \\
\text { head }\end{array}$ \\
\hline $\begin{array}{l}\text { Weight of stem leaves } \\
\text { and stem }\end{array}$ & 1 & 0.497 & 0.301 & 0.117 & 0.203 & 0.628 & 0.679 & 0.463 & 0.890 \\
\hline Weight of curd & & 1 & 0.848 & 0.615 & 0.540 & 0.796 & 0.807 & 0.998 & 0.838 \\
\hline Width of curd & & & 1 & 0.715 & 0.581 & 0.593 & 0.662 & 0.849 & 0.635 \\
\hline Height of curd & & & & 1 & 0.766 & 0.488 & 0.614 & 0.601 & 0.397 \\
\hline Length of stem & & & & & 1 & 0.477 & 0.583 & 0.522 & 0.411 \\
\hline Number of brunches & & & & & & 1 & 0.752 & 0.782 & 0.813 \\
\hline Weight of stem & & & & & & & 1 & 0.766 & 0.851 \\
\hline Weight of florets & & & & & & & & 1 & 0.815 \\
\hline $\begin{array}{l}\text { Weight of compact } \\
\text { head }\end{array}$ & & & & & & & & & 1 \\
\hline
\end{tabular}


Table 2. Correlation matrix for different quality parameters in the mean of varieties by open field production

\begin{tabular}{|c|c|c|c|c|c|c|c|c|c|}
\hline ON OPEN FIELD & $\begin{array}{c}\text { Weight of } \\
\text { stem leaves } \\
\text { and stem }\end{array}$ & $\begin{array}{l}\text { Weight of } \\
\text { curd }\end{array}$ & $\begin{array}{l}\text { Width of } \\
\text { curd }\end{array}$ & $\begin{array}{l}\text { Height of } \\
\text { curd }\end{array}$ & $\begin{array}{l}\text { Length of } \\
\text { stem }\end{array}$ & $\begin{array}{l}\text { Number of } \\
\text { brunches }\end{array}$ & $\begin{array}{l}\text { Weight of } \\
\text { stem }\end{array}$ & $\begin{array}{l}\text { Weight of } \\
\text { florets }\end{array}$ & $\begin{array}{c}\text { Weight of } \\
\text { compact } \\
\text { head }\end{array}$ \\
\hline $\begin{array}{l}\text { Weight of stem leaves and } \\
\text { stem }\end{array}$ & 1 & 0.667 & 0.683 & 0.054 & -0.248 & 0.720 & -0.010 & 0.727 & 0.923 \\
\hline Weight of curd & & 1 & 0.627 & 0.275 & -0.065 & 0.495 & 0.524 & 0.977 & 0.902 \\
\hline Width of curd & & & 1 & 0.006 & -0.283 & 0.403 & -0.010 & 0.678 & 0.719 \\
\hline Height of curd & & & & 1 & 0.737 & -0.207 & 0.391 & 0.213 & 0.173 \\
\hline Length of stem & & & & & 1 & -0.483 & 0.525 & -0.196 & -0.177 \\
\hline Number of brunches & & & & & & 1 & -0.107 & 0.582 & 0.673 \\
\hline Weight of stem & & & & & & & 1 & 0.350 & 0.264 \\
\hline Weight of florets & & & & & & & & 1 & 0.925 \\
\hline Weight of compact head & & & & & & & & & 1 \\
\hline
\end{tabular}

\section{References}

Astarini, I. A., Plummer, J. A., Lancaster, R. A., Yan, G. J. (2006): Genetic diversity of Indonesian cauliflower cultivars and their relationships with hybrid cultivars grown in Australia Scientia Horticulturae 108(2): 143-150. pp. DOI: 10.1016/j.scienta

Balázs, S. (2000): A zöldséghajtatás kézikönyve. Budapest. Mezögazda Kiadó. 494. pp.

Delahaut, K. A., Newenhouse, A. C. (1997): Growing broccoli, cauliflower, cabbage and other cole crops in Wisconsin, Uni of Wisc. 19 pp.

FAOSTAT Statistical Yearbook (2014): Food and Agriculture Organization of the United Nations, Rome, Italy, 2015, http://faostat.fao.org

Fehér, B.-né (2009): Érzékeny a mikroelemhiányra. Kertészet és Szőlészet 58.9:27

Gregory, E. W. (2015): Vegetable production and practices. CABI 10 pp.
Helyes, L., Pék Z., Szabó L. (2000): Effect of different water supply on water consumption and canopy temperature of cauliflower. Acta Horticulturae. 537(1): 393-397.

Hodossi, S., Kovács, A., Terbe, I. (2004): Zöldségtermesztés szabadföldön. Budapest. Mezőgazda Kiadó. 321 pp.

Kerns, D. L., Palumbo, J. C., Byrne, D. N. (1995): Insect pest management guidelines for cole crops, cucurbits, lettuce and leafy green vegetables. Univ. of Ariz., Coop. Extn. Publ. 195007, 34 pp.

Nimkar, S. A., Korla, B. N. (2014): Studies on comparison of biparental and F4 progenies in late cauliflower (Brassica oleracea L. var. botrytis). Int. J. Farm Sci. 4:27-34.

Sharma, S. R., Singh, P. K., Chable, V., Tripathi, S. K. (2005): A review of hybrid cauliflower development. J New Seeds. 6:151-193.

Stirling, K., Lancaster, R. (2005): Effect of alternative planting configurations on cauliflower development. Acta Horticulturae 694: 301-305. 